\title{
Halal Certification Obligations in 2019: Is It Possible to be Applied in Indonesia?
}

\author{
Puji Sulistyaningsih Chrisna Bagus Edhita Praja* Heniyatun Yulia Kurniaty \\ Faculty of Law, Universitas Muhammadiyah Magelang, Mayjend Bambang Soegeng Street, km.5, Mertoyudan, \\ Magelang, Indonesia
}

The research is financed by Ministry of Research, Technology and Higher Education, the Republic of Indonesia. Abstract

This study aims to demonstrate the implementation of the halal certification system and highlight the problems in the Halal certification process in Indonesia and focus on the process, information flow and actors involved in the Halal certification process. This study attempts to generate significant findings in the establishment of implementing regulations or technical guidelines in the halal certification process. The perpetrators of SME's become the object of research considering its obligation in conducting halal certification. The results of this study are $32 \%$ of SME's in the City of Magelang know the existence of UUJPH and who approved the halal certification obligations exist in 2019 only 25\%. The solution of the problem is (1) Socialization of UUJPH to SME's and related offices. (2) Cross subsidies, or other policies so that the cost is light, it would be better not to pay. (3) There is a need for rules as a guideline for implementation and technical guidance. (4) Easy conditions and fast process. (5) Immediately established BPJPH at the city/county level or residency.

Keywords: Halal Certification Obligations, SME's, Halal Product Guarantee

DOI: $10.7176 / J L P G / 82-06$

\section{INTRODUCTION}

The State of Indonesia has the obligations outlined in Article 29 paragraph 2 of the 1945 Constitution which guarantees the independence of every citizen to embrace his or her religion and to worship according to his religion and belief. To that end, the Government in 2014 ratified Law No. 33 of 2014 on Halal Product Guarantee (UUJPH) as one form of guarantee in the implementation of halal products.

UUJPH became a significant breakthrough of the Government for Indonesian Muslims. It is related to Allah's command in (Surah Al-Baqarah: 127) to consume only halal and good food. Before the emergence of UUJPH, halal certification in goods and services products is only voluntary, not mandatory. Halal issues have also led to various cases that horrendous and disturbing Muslims in Indonesia. Examples of cases are the glonggong cattle in $1999^{1}$, Ajinomoto case in $2000^{2}$, the case of meningitis vaccine in $2009^{3}$, the case of beef jerky from pork-bearing bearing "abon" in $2009^{4}$ and the last case of pork meatballs in May $2017^{5}$. The purpose of this UUJPH is to create create tranquility and stability in the community.

Article 4 of this UUJPH determines that every incoming, outstanding, and trading product in the territory of Indonesia shall be halal certified. This article provides comfort, safety, and certainty of Halal Product availability for the community in consuming and using the product. This study examines how far the implementation of UUJPH in Magelang city considering that the Law is a new regulation. The law is still not widely known by business actors, especially small and medium business actors (SMEs).

\section{A BRIEF OVERVIEW OF HALAL CERTIFICATION SYSTEMS}

\subsection{Halal Certification and Logo}

The word Halal is originated from Arabic word which means lawful and permissible according to Islamic Syariah law which refers to the teachings of Al-Quran and exemplary conduct of Prophet Muhammad (Peace and blessings of Allah be upon Him) as quoted in Hadith. The opposite of Halal is Haram which means forbidden ${ }^{6}$. In Al-Quran, Quran, there are various proofs of the Islamic teaching in Halal concept. Among it is the ayat (verse) from Surah Al-Baqarah which strongly recommend Muslim people to only consume what is lawful in terms of Islam and avoid the wrongful ones which are misguided from Satan. The meaning of the ayat is as follows:

"He has forbidden you only the Maitah (dead animal), and blood and the flesh of swine, and that which is slaughtered as a sacrifice for others than Allah (or has been slaughtered for idols, on which Allah's Name has not been mentioned while slaughtering). But if one is forced by necessity without willful disobethence, nor

\footnotetext{
${ }^{1}$ Rahmah Maulidia, 'Urgensi Regulasi Dan Edukasi Produk Halal Bagi Konsumen', Justitia Islamica, 10.2 (2013), $359-90$.

${ }^{2}$ Liputan6, 'Ramai-Ramai Menarik Ajinomoto', Liputan 6 (Jakarta, 2001).

${ }^{3}$ Rohmatin Bonasir, 'MUI: Vaksin Meningitis Haram', BBC Indonesia (Jakarta, 2009).

${ }^{4}$ Aan/nrl, 'BPOM: 5 Merek Dendeng/Abon Sapi Positif DNA Babi', Detik (Jakarta, 2009).

${ }^{5}$ Ramdhan Triyadi Bempah, 'Polres Bogor Amankan 7 Orang Terkait Bakso Oplosan Daging Babi', Kompas (Bogor, May 2017).

${ }^{6}$ Asnidar Hanim Yusuf, Syadiyah Abdul Shukor, and Ummi Salwa Ahmad Bustamam, 'Halal Certification vs Business Growth of Food Industry in Malaysia', Journal of Economics, Business and Management, 4.3 (2016), 247-51 <https://doi.org/10.7763/JOEBM.2016.V4.399>.
} 
transgressing due limits, - then is no sin on him. Truly, Allah is Oft-forgiving Most Merciful as quoted Al Baqarah 173

The basic principles of Halal certification are Halal (permissible) and Thoyyibban (wholesome) taken from Al-Quran, verse 168 Surah Al-Baqarah. Halal is an Arabic word which means allowed or permitted according to shariah (Islamic) law. On the other hand, Thoyyibban means good quality, safety, cleanliness, nutritious and authentic ${ }^{1}$

Singapore, Thailand and Indonesia are among the countries that have their own Halal certification body. ${ }^{2}$ also identified three government agencies that collaborate with MUIS in Halal certification and enforcement, namely Food Control Department, Ministry of Environment; Agro-Veterinary Authority, Ministry of National Department and Commercial Crime Department, Ministry of Home Affairs. Further, according to HDC, source from Halal Standard Institute of Thailand, the Central Islamic Committee of Thailand is responsible for Halal certification of slaughtering houses, process food and services. This Committee, in cooperation with the Thai government producing Halal food standard and issuance the Halal symbols. The Halal certificates and logos are issued by the Committee that complied with the Islamic requirements.

\subsection{Current Halal Certification System in Indonesia: Based on Law No. 33 of 2014 on Halal Product Warranty (UUJPH)}

In Indonesia, Halal Certificate issued by Majelis Ulama Indonesia (MUI) after the examination and analysis conducted by Institute for assessment of Food, Drug, and Cosmetics of Majelis Ulama Indonesia (LPPOM MUI) to see if the product requirement stipulated by LPPOM MUI ${ }^{3}$. However, in accordance with UUJPH that in the implementation of halal product guarantee in 2019 will be held by the Halal Product Guarantee Organizing Body (BPJPH). Halal Certification Standards in Indonesia include (1) Halal or Haram foods, medicines and cosmetics will refer to Islamic law. (2) MUI issued a Halal fatwa for food, medicine and cosmetics. This is the Halal standard. (3) LPPOM MUI formulates Halal Assurance System / HAS 23000 as Halal standard verification in Indonesia. ${ }^{4}$

In Indonesia, during the year 2010 - 2015 MUI has issued halal certificate as much as 309.115 halal certificates for product goods, more clearly will be seen in the figure below

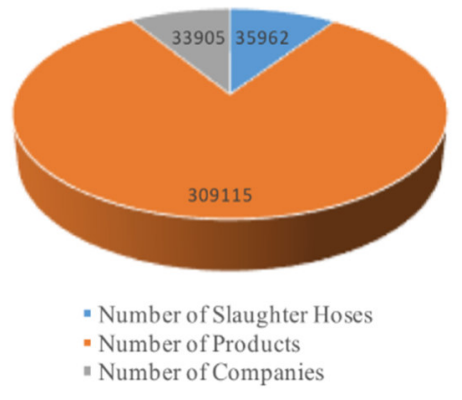

Figure 1. Implementation of MUI Certification ${ }^{5}$

From these data, the top 10 products certified halal can be seen in the following figure

\footnotetext{
${ }^{1}$ Shaikh Mohd, Aspects of Food Safety from the Islamic Perspective, Food and Technological Progress an Islamic Perspective (Kuala Lumpur, 2006).

${ }^{2}$ Mohammad Sadek, Marketing Niche for Halal Food Supply: A Framework for the Establishment of an International Halal Food Market (Kuala Lumpur: MPH, 2006)

${ }^{3}$ LPPOM MUI, General Guidelines of Halal Assurance System, LPPOM MUI, 2008.

${ }^{4}$ LPPOM MUI, 'Customer User Manual-Manufacturing', 2017, pp. 1-79.

${ }^{5}$ Vitto Rafael Tahar, 'Halal Regulatory Framework in Indonesia', 2017, pp. 1-19.
} 


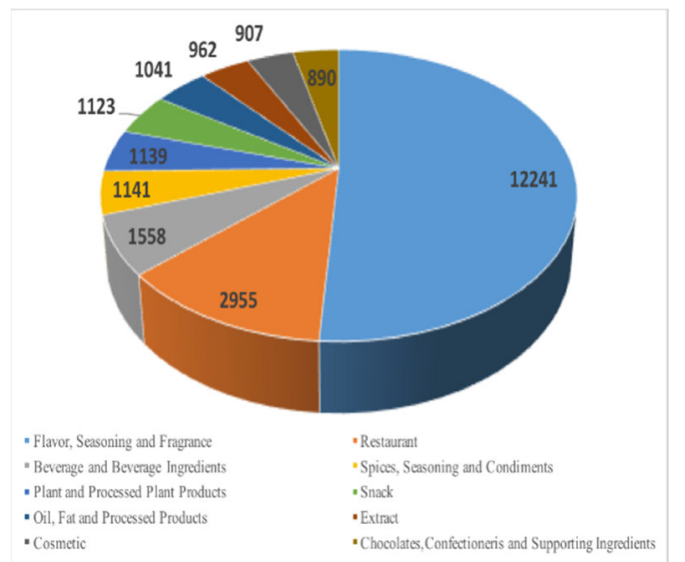

Figure 2. Top 10 products with MUI Halal Certificate ${ }^{1}$

Based on Law Number 33 The year 2014 regarding Halal Product Guarantee, Halal products are products that have been declared halal by Islamic Shari'a ${ }^{2}$. Whereas Products are goods and services related to food, beverages, medicines, cosmetics, chemical products, biological products, genetic engineering products and goods used, used, or utilized by the public. Based on the above explanation, the halal perception must not only be attached to food and beverage products but also services related to all things that are used and utilized by the community. Before this law, halal warranties have been implemented, but halal labels are limited to food, beverage, medicine, cosmetics, chemical products, biological products and genetic engineering products.

Currently In Indonesia, in the filing of halal certification can submit online with the following process

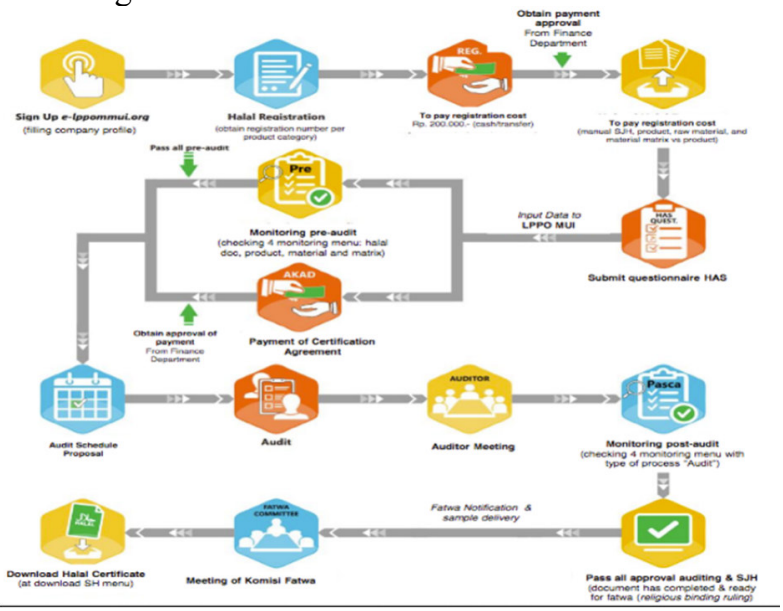

Figure 3. Online Halal Certification Flow Chart

With the ease of filing halal certification is expected to increase the quantity of the goods and services that will be certified in Indonesia. Moreover, halal certification in UUJPH is mandatory so that the obligation must be implemented by business actors.

\section{RESEARCH METHODOLOGY}

\subsection{Research aims and objectives}

This study aims to demonstrate the implementation of the halal certification system and highlight the problems in the Halal certification process in Indonesia. This study will focus on the process, information flow and actors involved in the Halal certification process. This study attempts to generate significant findings in the establishment of implementing regulations or technical guidelines in the halal certification process.

\subsection{Research design}

In this study, the perpetrators of SME'S become the object of research considering its obligation in conducting halal certification. Also, the Department of Industry and Trade, MUI and the Health Service of Magelang City also became the supporting object in this research. The function of the institution is as one of the facilitators in halal certification process. The summary of the research design is shown in Figure 4.

\footnotetext{
${ }^{1}$ Vitto Rafael Tahar.

${ }^{2}$ House of Representative of Indonesia Republic, Undang - Undang Republik Indonesia U No. 33 Tahun 2014 Tentang Jaminan Produk Halal, 2014, pp. $1-5<$ https://doi.org/10.1007/s13398-014-0173-7.2>.
} 


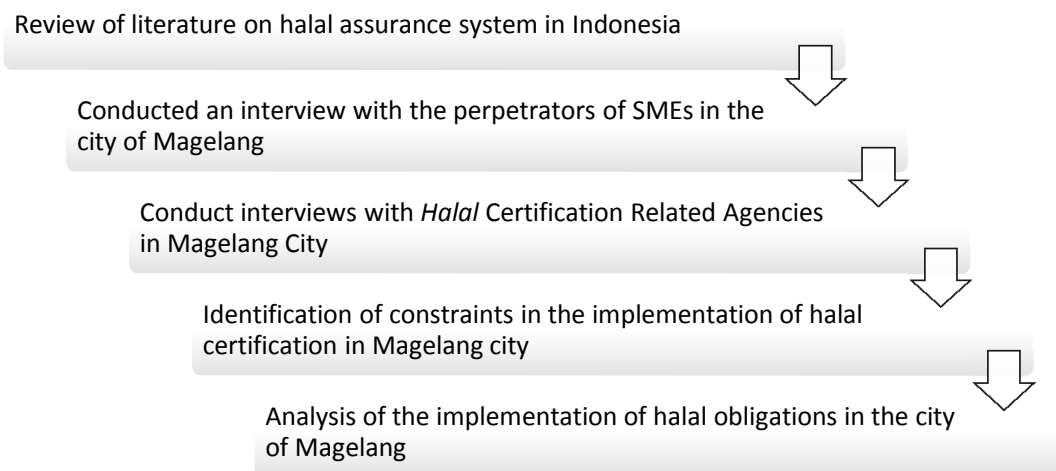

Figure 4. Research Design

\section{RESEARCH RESULT AND DISCUSSION}

\subsection{Perceptions of SMEs Actors on the Implementation of UUJPH}

The results of interviews with 28 SMEs Actors from a total of 49 SMEs registered in the city of Magelang as follows :

1 Tri Wahyuni-. Not knowing the existence of UUJPH, not yet know about halal registration. According to him, consumers still do not know the importance of halal label on a product of SME'S even though the product is guaranteed halal, according to him now there is or not its halal label on its product has no effect on consumer purchasing power. So, according to her, the halal label does not guarantee its product increases regarding sales. She is willing to take care of if not charged

2 Warno -. Not knowing the existence of UUJPH, not yet know about halal registration. According to him, the need for guidance to business actors and halal must also be from raw material makers, and this program should not burden business actors with expenses. He is willing to take care of if the cost is light.

3 Sri Widiyati-. Knowing the existence of UUJPH, knowing about halal registration. This process must be a long time and should be applied if it does not burden business actor with expensive cost because to protect consumer with halal then business actor also protected one of them free of charge management and extension. Willing to take care of if the cost is light or no cost.

4 Sutrisno-. Not knowing the existence of UUJPH, know about halal registration. According to him now does not affect consumer purchasing power. Not Willing to take care of.

5 Mansur-. Not knowing the existence of UUJPH, know about halal registration. According to him, it is critical that halal certification because it provides protection to consumers and according to Islamic teachings and has been certified halal. Willing to take care of if no cost.

6 Fendy N-. Not knowing the existence of UUJPH, not yet know about halal registration. According to him, still, do not know on what part and what is a service must have halal certification. Willing to take care of if the cost is light or no cost.

7 Dewi-. Knowing the existence of UUJPH, not yet know about halal registration. According to him until now business actors do not know anything about the enactment of this Act, the process was not yet known. Willing to take care of if the cost is light or no cost.

8 Ngadiyono-. Not knowing the existence of UUJPH, not yet know about halal registration. According to him less agree if the children toys from certified halal wood, still experiencing halal confusion on the part or in what regard, according to his experience take care like this will only hurt business actors such as SNI which was then only free at the beginning then there are levies that are not comparable with income because the cost is expensive so as to burden the business actors and the results are not satisfactory because although it has been labeled SNI, for example, does not affect consumer purchasing power at this time. Not willing to take care of.

9 F. Nur-. Not knowing the existence of UUJPH, not yet know about halal registration. According to him is very important because his business is very vulnerable to unlawful materials and in the process of taking care should be facilitated because the process is complicated. Willing to take care of if the cost is light or no cost.

10 Bagus P-. Not knowing the existence of UUJPH, not yet know about halal registration. According to him, the product is halal and if the government obliges it should be free because so as not to burden the business actor. Not knowing the existence of UUJPH, not yet know about halal registration. Willing to take care of if no cost.

11 Suharto-. Not knowing the existence of UUJPH, not yet know about halal registration. According to him, there are real rules but should be facilitated by the government in managing halal certification. Willing to take care of if the cost is light or no cost. 
12 Mamat-. Not knowing the existence of UUJPH, not yet know about halal registration. According to him still confused about how services must have halal certification, but the government program is good but especially in the local government is not okay, MSMEs feel trampled, let alone there is a duty like this there are usually costs that will burden and levies by an irresponsible person. Willing to take care of if no cost.

13 Tomi-. Knowing the existence of UUJPH, knowing about halal registration. He said halal certification is good, but nowadays it is very burdensome for business actors because it is expensive and can be said commercially, free early and expensive when the extension and even cost doubled and really apprehensive because for the sake of the safety of business consumers who hit the stone with burdened costs, registered business actor is annoyed and annoyed by the impression of being commercialized, his costs rise with the reasons for his immense and he thinks that the government should not. many business actors who do not finish taking care of it because expensive and now these labels have not affected the consumer's purchasing power so that it can be said this is the reason business players are reluctant to take care of halal certification and the like. Willing to take care of up to extension without charge.

14 Romadhon-. Not knowing the existence of UUJPH, knowing about halal. Agree to follow the rules made by the government. For micro business then do not burden.

15 Yanto-. Not knowing the existence of UUJPH, knowing about halal. The business carried out claimed by the business actor that in presenting the product is halal even though not yet have halal certification. Following the government rules as long as it does not harm MSMEs.

16 Avianto - Not knowing the existence of UUJPH, do not know about the registration halal. Consumer never ask about the services that are issued because the product it is assured of the quality of his services that he gave to consumers. If it is recommended to make UUJPH, it will be dealt with the caveats that he wants is while there is no cost program.

17 Sugianti- Already aware of UUJPH, but not yet known about the registration of halal, but if it is recommended to make UUJPH not willing for economic reasons want to take care of UUJPH but guaranteed by the government in the hope of no cost, easy terms, there are additional costs of products and facilities guaranteed.

18 Robbat- Not knowing the existence of UUJPH, not knowing about the registration of halal. According to him, lack of socialization with this law and if required to take care of it will make UUJPH above government regulation with rights and obligations.

19 Ernawati - Not knowing the existence of UUJPH and do not know about the registration of halal. The socialization that held the government so all SMEs can know what is important UUJPH and safe for consumers and the government also know the resulting product is halal and his request to the government about UUJPH is not complicated, simplified and not burdened with high cost.

20 Sudarsono - Not knowing the existence of UUJPH, and not yet know about the halal registration. If it must have halal certificate, it will soon be made with the reason for more consumer confidence and because of the majority of Muslims and currently not care for the scope of new products in traditional markets

21 Nadya - already know about the halal registration. Agree with UUJPH in the hope to keep her halal product, and consumers feel safe with the product produced

22 Lilik - already know and know about the halal registration. Not agree with the making UUJPH by assuming that it is not possible if getuk mixed with goods that are not kosher because of the main ingredients of cassava. The government's demand for UUJPH should be the government providing officers who are at least once a month to check halal certification for each business product. The consumer's response to this product is not in doubt because there is almost no consumer who doubts the product.

23 Irma - Already knowing and knowing about halal registration. It is assumed that halal product is important because it must be guaranteed to its halal so that people feel safe and secure and hope to the government give ease in managing halal certification if there are consumers who ask about the loss then there is certification of production food from the health department.

24 Ida Rahmawati - Not yet know UUJPH and not yet know about halal registration. Agreed with the UUJPH so that consumers more trust in goods and services products.

25 Ida Andriani - Not yet know UUJPH and about halal registration. the lack of socialization from the government to SMEs willing to take care of UUJPH, in other words, is not complicated in taking care of halal certification, business products are more in demand, better known to the public.

26 Hesti - not yet know and not yet know about registration. Too more consumers believe in a product and guarantee a product and when making in the easy and inexpensive.

27 Tri Narni - Not knowing about registration and difficulty in taking care of halal certification in the presence of the government's provisions may be lighter in its manufacture.

28 Sami - Not knowing about halal registration. Because not yet know UUJPH and lack of government attention to SME'S. However, he believes its products are maintained halal

From the above data, it is concluded from 28 (twenty-eight) in Magelang City that those who know about UUJPH are $32 \%$ and who agree about UUJPH's enforceability is $25 \%$. 
SME's Actors knowledge about UUJPH is still many who do not know it is necessary to socialize to SME's actors. From the results of research that has been done there are some suggestions on the validity of UUJPH, among others; (1)Socialization of UUJPH to SME'S and related offices. (2) Cross subsidies, or other policies so that the cost is light, it would be better not to pay. (3) There is a need for rules as a guideline for implementation and technical guidance. (4)Easy conditions and fast process. (5) Immediately established BPJPH at the city/county level or residency.

\subsection{Efforts Halal Certification Related Agencies in the Implementation of UUJPH \\ 4.2.1. Indonesian Religious Leader (MUI)}

In the process of halal certification, MUI is still trusted by the Government as an institution that performs its duty in the field of halal certification. According to H. Chamami, M.Si, MUI Magelang secretary, halal certification process that will be held by BPJPH until now there has been no follow-up on how the mechanism. However, regardless of the matter, the MUI strives to carry out its duties in the field of halal certification until the establishment of BPJPH. In Magelang City, there are only 5 SMEs who register their products for halal certified because in reality many do not know the urgency of the halal certification, especially in 2019 all products and services must register kosher certification. MUI stated that until now there had been no socialization regarding Halal Liability stated in UUJPH. In its implementation, MUI provides socialization through discussion forums concerning the obligation of routine halal certification although not yet targeted at the perpetrators of SME'S in Magelang.

\subsubsection{Department of Cooperatives, Industry and Trade (Diskoperindag)}

Department of Cooperatives, Industry, and Trade (Diskoperindag), which is an institution authorized to regulate and nurture micro-enterprises and regulate the trade of products on the market has not known and have never heard of Law No. 33 of 2014 on Halal Product Guarantee. Herwanto Tri Sungkono as Head of Cooperative and Micro Business Development conveyed that Diskoperindag has not obtained any socialization about UUJPH even just found out after this research was conducted. The same opinion is also by FX. Edi Winarno as Extension Industry and Trade Madya that has never read the Act.

According to FX. Edi Winarno UUJPH is very heavy to be done because halal certification procedure before regulated UUJPH it is very complicated, long and costly burdensome burden for micro business. Small businesses in the mobile community are burdened at the expense of taking halal certification. When this research is done, halal certification procedure is not easy because for micro business who want to take care of halal certification must have P-IRT or Household Industry License which process is not easy although facilitated by Diskoperindag which in one year done 2 (two) that is April and October.

Although in the handling of P-IRT facilitated, there are still many micro businesses are reluctant and do not want to take care of it. P-IRT is a requirement to register halal certification is still a lot that does not have, so it is unlikely that business actors to take care of halal certification. According to FX. Edi Winarno this is because; firstly the mindset of micro business actors who have not paid attention to the importance of having P-IRT, Halal Certification and so on to their products because they feel not with the permits of the products already sold in the market, and many of the businessmen argue that with or not with halal certification product on sale does not affect the interest of buying people, so it is considered unnecessary. Though it is very important to maintain security, comfort, and safety for the people who buy their products and for the business themselves.

Second, the conditions are difficult and spend time and costs are not small. Terms that are prepared very much like data and other permissions. Halal certification costs about IDR 2.000.000 (two million rupiahs) up to IDR 4.000.000 (four million rupiahs) and takes care of it at the provincial level MUI that is in Semarang which is quite far away which requires transportation and time cost so it should leave the job and not no guarantee to get away. The concern or disappointment that is felt is when the business actor is declared not to pass the inspection of the survey at the place of the business actor such as hygiene, hygienic factors and factors of production, the cost is considered to be forfeited but there is no guidance and notification of the reason why it is declared not qualified.

MUI should take the position as a government institution so that the implementation of halal certification is real to help and mitigate micro business to grow and develop. Even according to SME's actually, has helped the government to reduce unemployment then it is appropriate to get ease and to lighten it can be cross-subsidized. Cross subsidy means for a big factory hence high cost to subsidize micro business so that if cost then micro business do not mind. For example, the factory knows Yuka Magelang when the list costs Rp. 2,500,000 (two million five hundred thousand rupiahs) after 2 (two) years then renewed but charges charged IDR 6,500,000 (six million five hundred thousand rupiahs) incurred a cost increase of up to 3 (three) times the burden of the perpetrator the ending is not taken, and the certificate is not paid.

About the term of a halal certificate with the validity period of 2 (two) years and for the extension, it would be better to be made longer like 5 (five) years, so it does not bother the government because the time is short while many are taking care of halal certificate extension. Regarding UUJPH there should be guidance such as implementation guidance or technical guidance so that halal certification goal for all SME'S products can be 
achieved.

Efforts that have been made Diskoperindag support halal certification program, among others; 1) Technical and no technical training on business ; Technical training is about production, training for micro business actors regarding the production of goods or food such as making food, household goods, sewing cloth and so forth so that business actor smart regarding production, the product more attractive and follow market demand. Nontechnical training is about business management so that business actors can run their business right to get profit and more develop.2) Facilitating Consultation Assistance; Consultation and facilitating assistance in business and trade to trigger business actors or business actors in pioneering efforts to further develop.

\subsubsection{Public Health Office in Magelang City}

Public Health Service, especially Health Office of Magelang City in 2017 got a letter from Majelis Ulama Indonesia that about certification of halal products delegated to Health Department, but until this research done there is no implementing regulation or procedure as guidance for Health Department to serve business actor who will register their products to be halal certified. According to Devi as an employee of the Magelang City Health Office in the field of Human Resources that the Department of Health is currently still constrained how the regulations or procedures about certification of halal products, because in the past time the Health Office of Magelang Municipality has never been included or involved in the process of halal certification and yet there is no guideline, so we are confused.

Regarding the UUJPH Magelang City Health Office seems to have not understood and not yet known by all employees of Health Office this is supported by the results of interviews with Devi as an employee of the Magelang City Health Office in the field of Human Resources that do not know about the Halal Product Guarantee Organizer (BPJPH) even never heard of. Whereas BPJPH is the Agency that organizes the guarantee of halal products based on Article 1 point (1) UUJPH. Article 7 of UUJPH stipulates that BPJPH in exercising its authority may cooperate one of them with ministries and related institutions, furthermore in Article 9 UUJPH regulate that such cooperation regarding testing and or examination of products that actually institutions that are experts in the field one of them is the Health Department. The actual condition of Public Health Office did not know about BPJPH.

The situation as mentioned above can be said something that gives rise to legal vacuum. Very unfortunate when there are business actors want to register halal certification of its products will be hampered. So it can be concluded that the Magelang City Health Office has no effort related to the enforceability of Law No. 33 of 2014 About Halal Product Guarantee.

\section{CONCLUSIONS}

UUJPH which will be applied in 2019 in halal certification obligation until now there has been no socialization given to the perpetrators of SMEs in the City of Magelang. The perpetrators of SMEs in Magelang City majority do not agree on the halal certification obligation because the cost is quite expensive and only valid for four years. Also, the requirements are quite complicated to make SME'S actors are reluctant to take care of the halal certification. Therefore, some things should be done by the Government (1) Socialization of UUJPH to SME'S and related offices. (2) Cross subsidies, or other policies so that the cost is light, it would be better not to pay. (3) There is a need for rules as a guideline for implementation and technical guidance. (4) Easy conditions and fast process. (5) Immediately established BPJPH at the city/county level or residency.

In a regulation to be executed, an Implementation Regulation should be immediately established. As well as UUJPH, the implementation of the Act can run effectively with the existence of regulations that can be used as a reference in the implementation of the Halal Assurance System. Therefore, it is necessary to formulate rules that accommodate the guidelines for the perpetrators of SMEs in financing the halal certification.

\section{ACKNOWLEDGMENT}

The authors thank the members of the Editorial Advisory Board for their careful review and approval of these articles. The research was supported by the Ministry of Research, Technology and Higher Education, the Republic of Indonesia, through a Beginners Lecturer Research Grant. This work is also supported by the Research Division of Center of Research, Development and Community Services Universitas Muhammadiyah Magelang for Monitoring and Internal Evaluation facility. Researchers are grateful to all the institutions that have supported this research and to reviewers.

\section{References}

Aan/nrl, 'BPOM: 5 Merek Dendeng/Abon Sapi Positif DNA Babi', Detik (Jakarta, 2009)

Bempah, Ramdhan Triyadi, 'Polres Bogor Amankan 7 Orang Terkait Bakso Oplosan Daging Babi', Kompas (Bogor, May 2017)

Bonasir, Rohmatin, 'MUI: Vaksin Meningitis Haram', BBC Indonesia (Jakarta, 2009)

Hanim Yusuf, Asnidar, Syadiyah Abdul Shukor, and Ummi Salwa Ahmad Bustamam, 'Halal Certification vs Business Growth of Food Industry in Malaysia', Journal of Economics, Business and Management, 4 (2016), 
247-51<https://doi.org/10.7763/JOEBM.2016.V4.399>

Liputan6, 'Ramai-Ramai Menarik Ajinomoto', Liputan 6 (Jakarta, 2001)

LPPOM MUI, General Guidelines of Halal Assurance System, LPPOM MUI, 2008

Maulidia, Rahmah, 'Urgensi Regulasi Dan Edukasi Produk Halal Bagi Konsumen', Justitia Islamica, 10 (2013), 359-90

Mohd, Shaikh, Aspects of Food Safety from the Islamic Perspective, Food and Technological Progress an Islamic Perspective (Kuala Lumpur, 2006)

MUI, LPPOM, 'Customer User Manual-Manufacturing', 2017, pp. 1-79

Republic, House of Representative of Indonesia, Undang - Undang Republik Indonesia U No. 33 Tahun 2014 Tentang Jaminan Produk Halal, 2014, pp. 1-5 <https://doi.org/10.1007/s13398-014-0173-7.2>

Sadek, Mohammad, Marketing Niche for Halal Food Supply: A Framework for the Establishment of an International Halal Food Market (Kuala Lumpur: MPH, 2006)

Vitto Rafael Tahar, 'Halal Regulatory Framework in Indonesia', 2017, pp. 1-19 